\title{
Composition of $15-85 \mathrm{~nm}$ particles in marine air
}

\author{
M. J. Lawler ${ }^{1,2}$, J. Whitehead ${ }^{3}$, C. O'Dowd ${ }^{4}$, C. Monahan ${ }^{4}$, G. McFiggans ${ }^{3}$, and J. N. Smith ${ }^{1,2,5}$ \\ ${ }^{1}$ Atmospheric Chemistry Division, National Center for Atmospheric Research, Boulder, USA \\ ${ }^{2}$ Department of Applied Physics, University of Eastern Finland, Kuopio, Finland \\ ${ }^{3}$ Centre for Atmospheric Science, University of Manchester, Manchester, UK \\ ${ }^{4}$ School of Physics and Centre for Climate \& Air Pollution Studies, \\ National University of Ireland Galway, Ireland \\ ${ }^{5}$ Finnish Meteorological Institute, Kuopio, Finland
}

Correspondence to: M. Lawler (mlawler@ucar.edu)

Received: 15 November 2013 - Published in Atmos. Chem. Phys. Discuss.: 23 January 2014

Revised: 5 July 2014 - Accepted: 12 September 2014 - Published: 5 November 2014

\begin{abstract}
The chemical composition of $15-85 \mathrm{~nm}$ diameter particles was measured at Mace Head, Ireland, during May 2011 using the TDCIMS (thermal desorption chemical ionization mass spectrometer). Measurable levels of chloride, sodium, and sulfate were present in essentially all collected samples of these particles at this coastal Atlantic site. Acetaldehyde and benzoic acid were also frequently detected. Concomitant particle hygroscopicity observations usually showed a sea-salt mode and a lower hygroscopicity mode with growth factors near to that of ammonium sulfate. There were many periods lasting from hours to about 2 days during which the $10-60 \mathrm{~nm}$ particle number increased dramatically in polar oceanic air. These periods were correlated with the presence of benzoic acid in the particles and an increase in the number of lower hygroscopicity mode particles. Very small $(<10 \mathrm{~nm})$ particles were also present, suggesting that new particle formation contributed to these nanoparticle enhancement events.
\end{abstract}

\section{Introduction}

Particles in the atmosphere play important roles in the global climate through direct interaction with radiation and by acting as cloud condensation nuclei (CCN). Understanding controls on cloud extent and type is critical for predicting future climate (Solomon et al., 2007). The formation of particles from gas phase species in the atmosphere is likely a significant contributor to aerosol number and atmospheric optical depth in a variety of environments, and this pro- cess may therefore influence $\mathrm{CCN}$ concentrations (Kulmala et al., 2004; Wang and Penner, 2009; Yu and Luo, 2009; Spracklen et al., 2006). Water vapor uptake on small, recently formed particles is limited by the Kelvin effect, so new particles must grow via uptake of other species before they are large enough to act as CCN. In the marine boundary layer (MBL), where cloud water vapor supersaturations are typically around $0.2 \%$, even very hygroscopic sea-salt aerosols must be greater than $70 \mathrm{~nm}$ in diameter before they are activated into cloud droplets (Hoppel et al., 1996; Seinfeld and Pandis, 1997). For this reason, in order for homogeneously nucleated particles to have a significant impact on cloud formation, they must grow swiftly enough to $\mathrm{CCN}$ size before they are lost by coagulation onto existing aerosol. Net condensation of low volatility vapors and/or multiphase reactive uptake are required to accomplish this growth (Khvorostyanov and Curry, 2007; Donahue et al., 2011).

Sulfuric acid $\left(\mathrm{H}_{2} \mathrm{SO}_{4}\right)$ is thought to be critical for particle nucleation throughout the atmosphere, and it has been shown to contribute to nanoparticle growth (Kuang et al., 2008; Eisele and McMurry, 1997; Bzdek et al., 2012). However, beyond the very initial stages of particle formation, $\mathrm{H}_{2} \mathrm{SO}_{4}$ probably plays a small role in boundary layer particle growth (Kuang et al., 2012, 2008; Zhang et al., 2012). Observations from a variety of environments suggest that condensation of organic vapors contributes greatly to particle growth for particles of diameters larger than $\sim 10 \mathrm{~nm}$ (Kuang et al., 2012; Bzdek et al., 2011; Donahue et al., 2011; Ehn et al., 2014). Multifunctional acidic organic species are thought to be 
likely contributors to particle growth due to their low vapor pressures (Zhang et al., 2012). Highly oxidized "extremely low volatility organic compounds" (ELVOCs) appear to play an important role in new particle growth in the boreal forest (Ehn et al., 2014). Recently nucleated particles have been observed in coastal regions that experience large sea-air fluxes of readily photolyzable iodine-containing species (O'Dowd and Hoffmann, 2005; Mäkelä, 2002; Whitehead et al., 2009; McFiggans et al., 2010; Whitehead et al., 2010).

The particle distribution in the MBL is an important climate parameter due in part to the large areal extent of the global oceans. The MBL is characterized by relatively low particle concentrations compared to the terrestrial boundary layer (Heintzenberg et al., 2000; Spracklen et al., 2010). Small changes in particle number are therefore more likely to have an effect on ensemble aerosol properties and CCN numbers, and newly formed particles have more time to grow to $\mathrm{CCN}$ size before coagulation than in more polluted regions. For example, Pierce and Adams (2006) showed that the inclusion of small sea-salt aerosols in a general circulation model increased the $\mathrm{CCN}$ concentrations in some regions as much as $500 \%$. Also, cloud albedo is in general significantly higher than ocean albedo, making the relative per-area radiative impacts of cloud formation high. An understanding of how CCN are formed in the MBL is necessary for good parameterizations of cloud formation over the global oceans.

Submicron MBL particles are typically found in two dominant modes of number concentration: an accumulation mode centered around a $150 \mathrm{~nm}$ in diameter, aand an Aitken mode centered around $50 \mathrm{~nm}$ in diameter (Heintzenberg et al., 2000). The minimum in number concentration between these two modes has been attributed to cloud processing of particles (Hoppel et al., 1986; Fitzgerald, 1991). Particles of less than $50 \mathrm{~nm}$ diameter either quickly grow, are accommodated onto existing aerosol, or are deposited to the sea surface, depending on the availability of condensable vapors and the magnitude of the aerosol condensation sink (McMurry, 1983). While sea salt is understood to be the primary component of supermicron MBL aerosol, the composition and origin of smaller MBL particles remains a subject of debate after decades of study.

Sea spray from wave breaking is known to contribute to MBL particle populations down to at least $10 \mathrm{~nm}$, and presumably to even smaller sizes based on lab and in situ studies (O'Dowd and de Leeuw, 2007; Clarke et al., 2006; Russell and Singh, 2006). Clarke et al. (2003) showed that wave breaking contributed significantly to sub-100 nm particles measured at a coastal site, with a peak in the number distribution at $\sim 30 \mathrm{~nm}$. These small emitted particles are thought to be substantially enhanced in organics relative to bulk seawater, and it has even been suggested that sea spray under $200 \mathrm{~nm}$ contains no sea salt (Bigg and Leck, 2008). Ault et al. (2013) have shown that the organic fraction of sea spray generated mechanically in the lab increases substantially with biological activity in the seawater. For the smallest sizes measured (30-60 nm), mixed sea salt-organic (SS-OC) particles were sometimes observed, but organic carbon (OC) particles containing no sea salt were the most abundant. For the range $60-100 \mathrm{~nm}, \mathrm{SS}-\mathrm{OC}$ particles represented $50 \%$ of the sample before the addition of phytoplankton and heterotrophic bacteria, after which OC particles clearly dominated.

Ambient samples of MBL aerosol show that accumulation mode particles contain significant fractions of sulfate and organics (Mcinnes et al., 1997; Allan, 2004). Much of the sulfate found in small marine aerosols under clean conditions likely derives from the atmospheric oxidation of dimethyl sulfide emitted from the ocean. While $\mathrm{H}_{2} \mathrm{SO}_{4}$ has been shown to be a key species in particle nucleation and growth at many (mostly terrestrial) locations, the extent to which this process occurs over the open ocean remains an open question. Recent laboratory studies suggest that photosensitized reactions in the sea surface microlayer could lead to the formation of secondary organic aerosol (George et al., 2014). Observations at Mace Head, Ireland, show evidence for apparent open ocean particle production characterized by enhancements in particle number in the $15-50 \mathrm{~nm}$ diameter range as well as slow growth rates on the order of $0.8 \mathrm{~nm} \mathrm{hr}^{-1}$ (Dall'Osto et al., 2011; O'Dowd et al., 2010). Total number concentrations during these conditions were on average about eight times larger than for background conditions (Dall'Osto et al., 2011).

We present measurements of nanoparticle chemical composition and hygroscopicity made in marine air at Mace Head during May 2011. These observations provide insights into the formation and growth of small marine particles, with implications for the role of new particle formation in marine atmospheric chemistry and climate.

\section{Site and methods}

\subsection{Mace Head}

The Mace Head Atmospheric Research Station is located on the west coast of Ireland at $53^{\circ} 20^{\prime} \mathrm{N}, 9^{\circ} 54^{\prime} \mathrm{W}$. Measurements of the molecular composition of marine nanoparticles were made between 14 and 31 May 2011, during the Marine Aerosol-Cloud Interactions (MaCloud Inc.) campaign. During this period, the air temperature ranged from 7.6 to $13.4{ }^{\circ} \mathrm{C}$, with a mean of $11.0^{\circ} \mathrm{C}$ and typical diel range of $2-$ $3{ }^{\circ} \mathrm{C}$. The relative humidity ranged from 56 to $98 \%$, with a mean of $82 \pm 10 \%$ ( $1 \mathrm{SD}$ - standard deviation). Winds were consistently onshore, typically from $\mathrm{W}$ to $\mathrm{SW}$, and they ranged from $3.1-25.2 \mathrm{~m} \mathrm{~s}^{-1}$, with a mean of $10.9 \pm 3.1 \mathrm{~m} \mathrm{~s}^{-1}$ (1 SD). Air mass back trajectories were calculated for air arriving at the site using the NAME III dispersion model (Numerical Atmospheric dispersion Modeling Environment; UK Met Office) and the HYSPLIT model (HYbrid SingleParticle Lagrangian Integrated Trajectory; NOAA) (Draxler 
and Hess, 1997). The air masses arriving at the site originated in polar regions, North America, and the subtropics, but rarely if at all from continental Europe.

Particle size distributions were measured using a pair of scanning mobility particle sizers (SMPS). One consisted of a long differential mobility analyzer (DMA; model 3081, TSI, Inc.) and condensation particle counter (CPC; model 3010, TSI, Inc.) and the other consisted of a nanoDMA (model 3085; TSI, Inc.) and an ultrafine CPC (model 3025A, TSI, Inc.). SMPS measurements were performed continuously with a roughly 3 min time resolution.

\subsection{TDCIMS instrument}

Particle chemical composition was measured using the thermal desorption chemical ionization mass spectrometer (TDCIMS). This instrument has been described in detail elsewhere (Smith et al., 2004; Voisin et al., 2003). The instrument draws ambient air through a pair of unipolar chargers (UPCs), where small particles are efficiently charged by ion diffusion (Chen and Pui, 1999). The particles are size selected in radial differential mobility analyzers, or RDMAs (Zhang et al., 1995), operating at low resolution (McMurry et al., 2009). Particle mobilities corresponding to singly charged particles of 15,20 , or $30 \mathrm{~nm}$ diameter are selected for analysis based on ambient aerosol size distributions. Charged, size-selected aerosols are electrostatically precipitated onto a loop of $\mathrm{Pt}$ wire maintained at $4000 \mathrm{~V}$ relative to ground for a typical sampling time of $30 \mathrm{~min}$. The wire is shielded from contamination from neutral aerosols and gases by a sheath of clean $\mathrm{N}_{2}$. After the collection period, the wire is translated into an ion source region containing an ${ }^{241} \mathrm{Am}$ alpha-emitting radioactive foil. Here the wire is heated by a $70 \mathrm{~s}$ programmed current ramp and soak from room temperature to $\sim 600^{\circ} \mathrm{C}$ to desorb the compounds contained in the collected aerosol. The reagent ions generated by the ion source react with desorbed compounds from the collected aerosol to form product ions, which are passed through a collisional dissociation chamber and an octopole ion guide before being detected with a mass spectrometer.

The TDCIMS is capable of observing ions of both polarities, but only one polarity for a given sample. At all times, the ion source is filled with ultrahigh purity $\mathrm{N}_{2}$ gas. The reagent ions are provided by small impurities in the $\mathrm{N}_{2}$. In negative ion mode, the reagent ions are $\mathrm{O}_{2}^{-}$and $\left(\mathrm{H}_{2} \mathrm{O}\right)_{n} \mathrm{O}_{2}^{-}$clusters. This chemistry is particularly effective for generating deprotonated ions from strong gas phase acids (both organic and inorganic) (Smith and Rathbone, 2008). In positive ion mode, the reagent ions are $\mathrm{H}_{3} \mathrm{O}^{+}$and larger water clusters. Ammonia, amines, and some oxygenated hydrocarbons can be ionized by this chemistry, which usually results in protonated molecular ions. The ions observed result from different heating and volatilization processes for different compounds. Ammonium sulfate thermally decomposes before it desorbs appreciably, while many organic compounds can desorb as whole molecules. The melting point of sodium chloride is $801^{\circ} \mathrm{C}$ (Sirdeshmukh et al., 2001), but $\mathrm{Na}^{+}$and $\mathrm{Cl}^{-}$were nonetheless detectable in this study. This was probably due both to the decrease in melting point for very small (nonbulk) crystals (Breaux et al., 2004) and the desorption of less volatile species like $\mathrm{NaOH}$ and $\mathrm{HCl}$.

The instrument was operated on a roughly $2 \mathrm{~h}$ cycle including aerosol collection and a "background" for both positive and negative ions. The background signal is assessed using the same procedures as the collection, but without applying a collection voltage to the wire. The background signal therefore represents the accumulation of neutral gases and/or particles on the wire, due either to diffusion of gases from nearby instrument surfaces or to some of the sample air mixing into the $\mathrm{N}_{2}$ sheath gas flowing past the wire, as well as the contribution by any semivolatile species that desorb from the walls of the ion source while the collection wire is heated during analysis. Both collection and background signals represent integrated "desorption period" ion counts, which have a predesorption baseline signal removed. To achieve better high resolution (HR) fitting, the baseline and desorption period data are each averaged before fitting HR peaks. The signals are scaled at every averaged point by an averaged reagent ion signal to account for changes in sensitivity arising due to any changes in the reagent ion concentration. The reported aerosol composition measurements here have had the background signal subtracted. Signal errors were estimated as the square root of counted ions, and errors were propagated for all arithmetic operations. A detectable signal was defined as background-corrected signals which were two standard errors above zero.

The TDCIMS signals are reported here as fractions of the total detectable ion signal for each collected mass spectrum. This was done, rather than using the absolute ion signal or collected mass- or volume-normalized ion signal, to avoid uncertainties and potentially misleading interpretations stemming from the variability in particle volume and sizes collected. Estimated uncertainties in the collected mass are significant, usually on the order of $50 \%$ but sometimes higher, based on the error in the fitting approach described below and in the Supplement. The uncertainty is primarily due to the effects of multiple charging in the unipolar chargers (McMurry et al., 2009). A water-based condensation particle counter (CPC; model 3787; TSI Inc.) was located downstream of the TDCIMS collection wire. This allowed for an accurate assessment of the number collected, by comparing sampling and background particle concentrations. To estimate the particle volume collected, it was necessary to estimate the size distribution of collected particles. This depends on the ambient distribution, the selected electrical mobility, the sizedependent transmission and collection efficiency, and the distribution of charge number for a given particle size. The collected volume estimation was performed using laboratory observations of multiple charging and transmission in the system, alongside an inverse model that optimized an empirical 


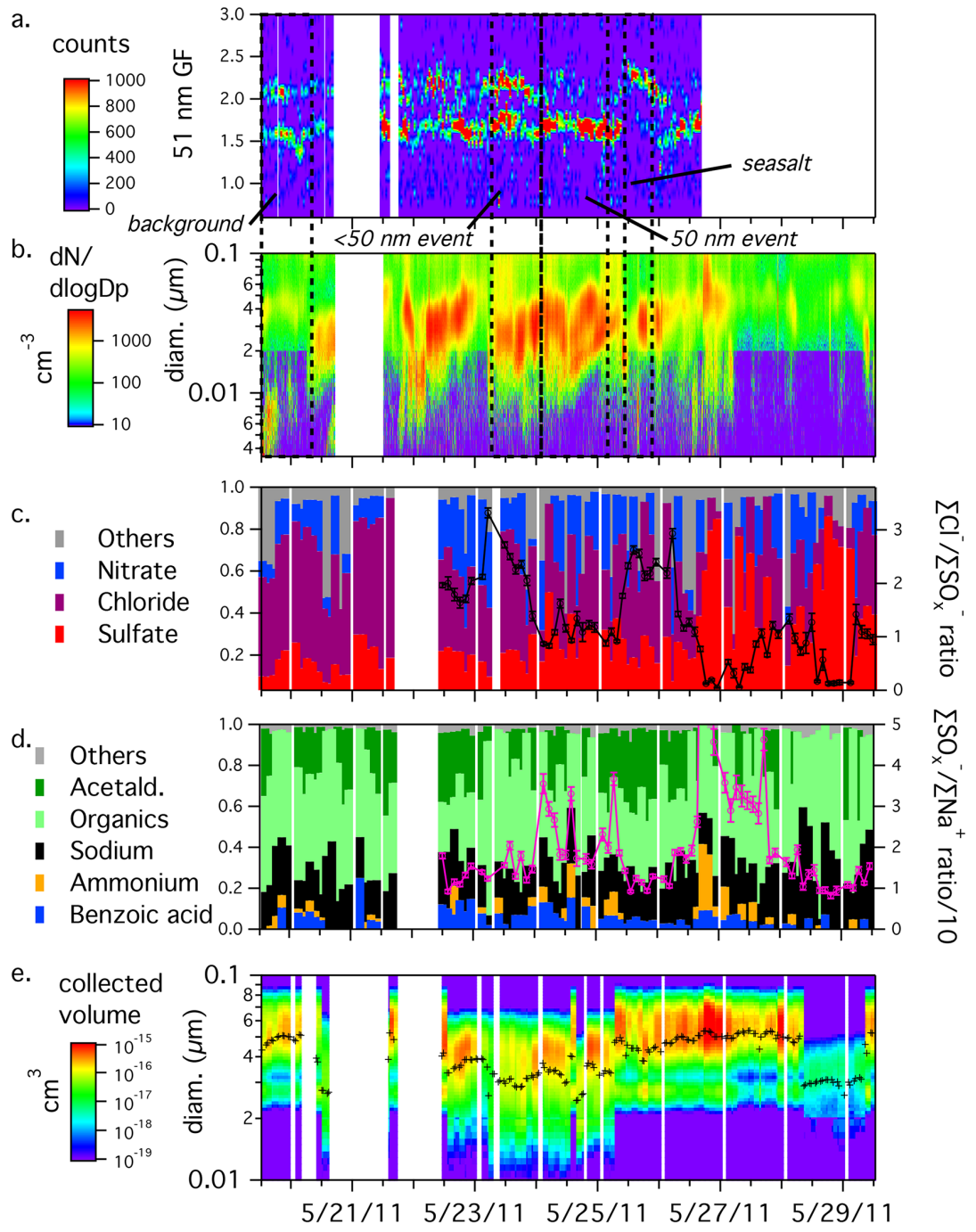

Figure 1. (a) Hygroscopic growth factor for $51 \mathrm{~nm}$ dry diameter particles. (b) Ambient particle size distribution. (c) Fractional ion type abundance for negative spectra and sum of chloride ions to sum of sulfate ions ratio (black points). (d) Fractional ion type abundance for positive spectra and sulfate to sodium ratio (magenta points, two volcano plume points clipped). (e) Estimated volume of collected aerosol in each size bin $\left(\mathrm{cm}^{-3}\right)$ and volume mean diameter for each collection (black crosses).

sampling efficiency function to match observed ambient particle size distributions to the TDCIMS CPC number concentrations. The approximate maximum sizes of collected particles for nominal 15,20 , and $30 \mathrm{~nm}$ singly charged particles are 50,65 , and $85 \mathrm{~nm}$, respectively. The details of the fitting procedure can be found in the Supplement. While the model is a somewhat imprecise tool, it gives a qualitative picture of which size of ambient particles made up the bulk of the mass sampled for each collection. An estimate of collected particle volume by particle size is plotted, along with the volume mean diameter for collected particles (Fig. 1e).

Just prior to the campaign, the TDCIMS was modified to improve chemical specificity via the replacement of the quadrupole mass spectrometer with a high resolution timeof-flight mass spectrometer (HTOF; TofWerk AG). Associ- ated with that modification, the vacuum chamber and ion optics were redesigned to interface the atmospheric pressure ion source with the HTOF. Several observations, both during the campaign and after post-campaign instrument modifications, suggest that the initial designs of the vacuum chamber and ion optics resulted in poor ion transmission and excessive collisional dissociation of analyte ions. This had the effect of low sensitivity for positive ions in general and, we suspect, for organic species during these measurements.

A chemical calibration of the TDCIMS was performed on 30 May 2011 using ammonium sulfate aerosol generated by a nebulizer. This resulted in clear $\mathrm{SO}_{2}^{-}$and $\mathrm{SO}_{4}^{-}$signals in the negative ion spectrum of gas phase $\mathrm{SO}_{2}$ or $\mathrm{SO}_{3}$, suggesting that the very recalcitrant ammonium sulfate thermally decomposed on the wire rather than desorbing as a neutral salt. 
There was a negligible response in the positive ion spectrum to the ammonium sulfate calibration aerosol; however, ammonium was detected in some ambient mass spectra. Later laboratory measurements indicated that ammonium nitrate was detected as $\mathrm{NO}_{2}^{-}$in the negative ion spectrum. Some organic nitrates would likely appear as $\mathrm{NO}_{2}^{-}$as well. The instrument is roughly 100 times more sensitive to ammonium nitrate (as $\mathrm{NO}_{2}^{-}$) than to ammonium sulfate (as $\mathrm{SO}_{2}^{-}$), based on laboratory calibrations. The instrument is comparably sensitive to ammonium sulfate and $\mathrm{NaCl}$ in negative ion mode.

\subsection{HTDMA instrument}

Aerosol growth factors were measured at Mace Head using the Manchester custom-built hygroscopicity tandem differential mobility analyser (HTDMA; (Duplissy et al., 2009)). The growth factor (GF) is defined here as the ratio between the aerosol's equilibrium diameter at $90 \%$ relative humidity (RH) and its dry diameter $(<15 \% \mathrm{RH})$. To measure this, the sample was drawn first through a membrane drier, to bring the $\mathrm{RH}$ down to $<15 \%$, then through a charge neutralizer. The first DMA was then used to select a particle size. This quasi-monodisperse aerosol sample was humidified at $90 \%$ $\mathrm{RH}$ before being passed into a chamber where the temperature was maintained at $2-3{ }^{\circ} \mathrm{C}$ below the first DMA, for a residence time of around $10 \mathrm{~s}$. A second DMA was then used to size scan the humidified aerosol, with particle detection provided by a water-based CPC (TSI model 3782), resulting in a GF distribution as a function of dry diameter $\left(\mathrm{GF}\left(D_{0}\right)\right)$. The raw data were inverted using the TDMAinv software described by Gysel et al. (2009). The nominal resolution of the instrument is 0.05 in GF space. The aerosol dry diameters selected during this campaign were 51, 75, 109, 162 and $258 \mathrm{~nm}$, and GF was scanned between 0.8 and 2.8. The sizes most relevant for comparison to the TDCIMS data are 51 and $75 \mathrm{~nm}$. The sample flow rate was maintained at $0.45 \mathrm{lpm}$ (liters per minute), and the DMA sheath flows at $4.5 \mathrm{lpm}$.

Full descriptions of the calibrations needed for HTDMA measurements are given by Good et al. (2010). Briefly, dry scans (no humidification, $\mathrm{RH}<15 \%$ ) were performed on a weekly basis in order to correct for the system transfer function, and for any offset between the DMAs. A size calibration of the first DMA was also performed at the start of measurements using latex spheres of a known size. In addition, a salt calibration was performed at the start and end of measurements, whereby an inorganic salt solution (typically ammonium sulfate or sodium chloride) was nebulized and sampled by the HTDMA at a set dry size of $150 \mathrm{~nm}$. The RH was then scanned over a range of values to produce a humidogram (mean GF as a function of RH), which can be compared to modeled values from the Aerosol Diameter Dependent Equilibrium Mixing Model (ADDEM) (Topping et al., 2005).

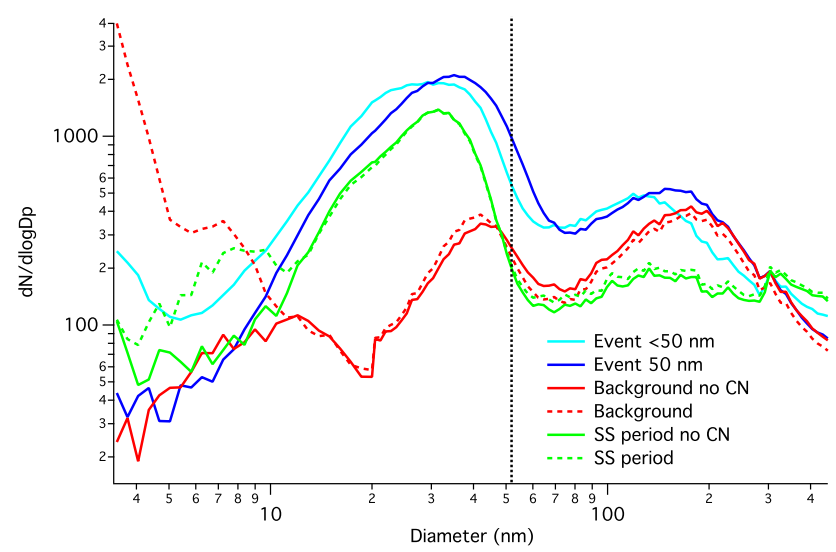

Figure 2. Mean particle size distributions for the four defined particle type periods. Coastal nucleation $(\mathrm{CN})$ was observed during the background and sea-salt periods used for HTDMA averages, and the plots show those periods both with and without the $\mathrm{CN}$ events. The dashed vertical line indicates the dry size for which HTDMA observations were made.

\section{Results}

\subsection{Background particles and events}

Typical submicron background particle size distributions showed two main modes, an accumulation mode with a number peak around $200 \mathrm{~nm}$ and an Aitken mode with a number peak around 50-60 nm (Fig. 2). Typical total integrated aerosol number concentration was on the order of $500 \mathrm{~cm}^{-3}$. There were also periods of up to a few hours during which background aerosol concentration was low, roughly $200-300 \mathrm{~cm}^{-3}$. The lowest recorded concentration was $\sim 100 \mathrm{~cm}^{-3}$.

On several occasions, lasting from hours to about 2 days, there were large increases in the concentrations of 10 $60 \mathrm{~nm}$ particles (Figs. 1b, 2). The total particle number during these "nanoparticle enhancement events" was typically $1000-2000 \mathrm{~cm}^{-3}$. During these events, there were also less pronounced but clear increases in particle number at sizes smaller than the main enhancement band, sometimes down to the roughly $4 \mathrm{~nm}$ cutoff size of the instrument. The enhancement events were primarily associated with polar air masses advected over the ocean and were very similar to the apparent open ocean particle production inferred by previous measurements at Mace Head (O'Dowd et al., 2010). During the same study, a new particle formation event was observed at sea about $8 \mathrm{~h}$ upwind of Mace Head, and the resulting plume showed nanoparticle number enhancements when it reached Mace Head (Ehn et al., 2010). During the present study, the strongest, most consistent period of enhancement events occurred from 22 to 25 May, when air masses reaching the site traveled in the marine boundary layer on a trajectory that passed between Greenland and Iceland (Fig. 3). The other major fine particle enhancement period was during the 


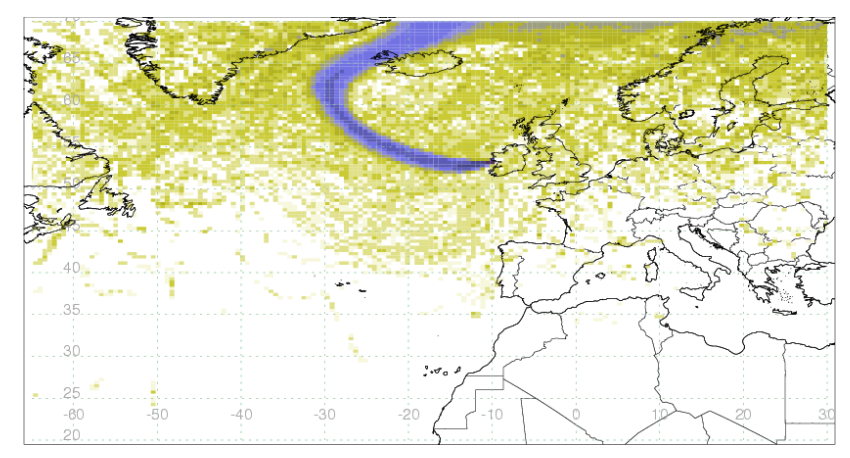

Figure 3. Time-integrated air history plot showing the recent surface $(0-100 \mathrm{~m})$ influence of the air arriving at Mace Head between 15:00 and 18:00 on 24 May 2011. The darker colors represent greater influence. This transport pattern was characteristic of the nanoparticle enhancement period of 23-24 May.

May 18-19 period and was characterized by air masses originating from a more westerly direction, closer to southern Greenland. About $25 \%$ of the sample period from May 14 to 31 was characterized by nanoparticle enhancement events of one of the two types defined here $(<50$ or $50 \mathrm{~nm})$. Apparent coastal nucleation events also occurred, during which there were large, brief increases in $<10 \mathrm{~nm}$ particles. These coastal nucleation particles were too small to be analyzed with either the TDCIMS or the HTDMA, and we do not directly comment further on them in this work. The nanoparticle enhancement events referred to in the rest of this work pertain to the periods of strong $10-60 \mathrm{~nm}$ number concentration enhancement.

\subsection{HTDMA observations}

The HTDMA size bin closest to the sizes measured by the TDCIMS was at a $51 \mathrm{~nm}$ dry mobility diameter. It is worth noting that the particle number enhancements during the events sometimes included 50-60 nm diameter particles and sometimes were confined to smaller sizes. For most of the measurement period, there were two distinct GF modes, one around $1.5-1.7$ and one around 2-2.3 (Fig. 4). The higher growth factor mode corresponds to highly hygroscopic sea salt, potentially at different degrees of aging. The lower GF mode could contain ammonium sulfate or some mixture of inorganic and organic components (Sjogren et al., 2007; Hersey et al., 2009). In particular, sodium salts of organic acids have hygroscopicities in this range (Wu et al., 2011; Peng and Chan, 2001). For larger marine particles measured in the eastern Atlantic, a GF of about 1.7 was attributed to internally mixed sulfate, ammonium, and organic particles (Allan et al., 2009).

We identified four characteristic particle distributions based on the SMPS and HTDMA observations, and averaged the particle size and hygroscopicity data over these periods (Figs. 2, 4). The periods were (1) a nonevent pe-

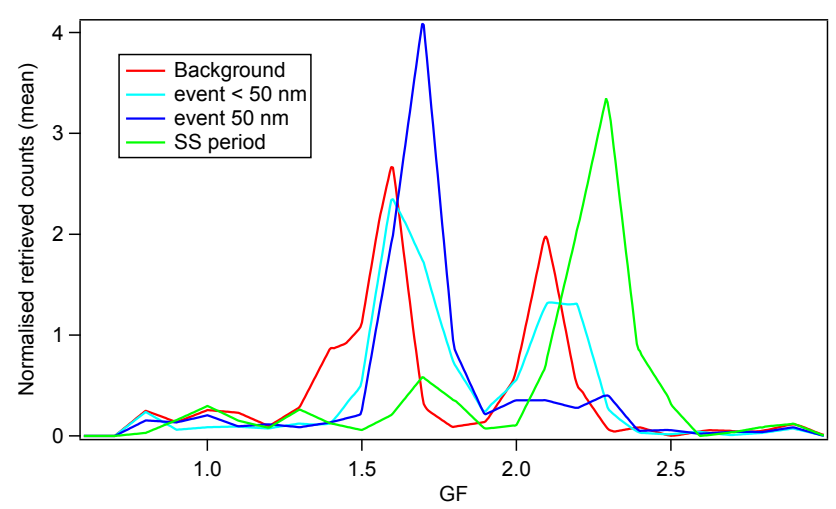

Figure 4. Averaged HTDMA GF distributions for $51 \mathrm{~nm}$ dry diameter particles for the four characteristic periods during the observations. There were usually two main modes, a sea-salt mode with GF $>2$, and a GF 1.5-1.7 mode that probably includes sulfate, sea salt and organics.

riod (background), 12:30 on 19 May-08:00 on 20 May; (2) nanoparticle enhancement events with major enhancements only for particles smaller than $50 \mathrm{~nm}$ ( $<50 \mathrm{~nm}$ events), 06:00 on 18 May-07:00 on 19 May and 06:00-24:00 on 23 May; (3) nanoparticle enhancement events in which the number enhancements included $50 \mathrm{~nm}$ or greater particles $(50 \mathrm{~nm}$ events), 14:00-24:00 on 22 May and 00:00 on 24 May-04:00 on 25 May; and (4) a period dominated by one high hygroscopicity mode (sea salt or SS) in the $51 \mathrm{~nm}$ HTDMA sample bin, 10:00-19:00 on 25 May. Average SMPS and HTDMA data for each characteristic period type are presented in Figs. 4 and 2. Examples of the different period types are shown in Fig. 1a and b. During background conditions and $<50 \mathrm{~nm}$ event conditions, both the $1.5-1.7$ and $2-2.3$ GF modes tended to be present. However, during events in which there were large enhancements in $>50 \mathrm{~nm}$ particles, the highly hygroscopic mode decreased sharply and the 1.51.7 GF mode became larger (Fig. 4). This decrease was observed for particles up to the $162 \mathrm{~nm}$ bin size (not shown). Coastal nucleation occurred during part of the background and sea-salt periods, but it did not appear to affect the measured hygroscopicities at $51 \mathrm{~nm}$.

\subsection{TDCIMS particle mass spectra}

The TDCIMS negative ion particle spectra were dominated by $\mathrm{Cl}^{-}, \mathrm{SO}_{2}^{-}, \mathrm{NO}_{2}^{-}$, and $\mathrm{SO}_{4}^{-}$(Fig. 5b). A subset of the time series is plotted in Fig. 1c as fraction of total ion signal above detection for each mass spectrum. $\mathrm{SO}_{2}^{-}$and $\mathrm{SO}_{4}^{-}$ are indicators of sulfate $\left(\mathrm{SO}_{4}^{2-}\right)$ in the particles. $\mathrm{NO}_{2}^{-}$is an indicator of nitrate $\left(\mathrm{NO}_{3}^{-}\right)$in the particles, potentially inorganic or organic in origin. The instrument is very sensitive to nitrate, so the relative nitrate concentrations in the particles are likely much lower than suggested by the relative ion abundances. Nitrate can also be prominent in the background 

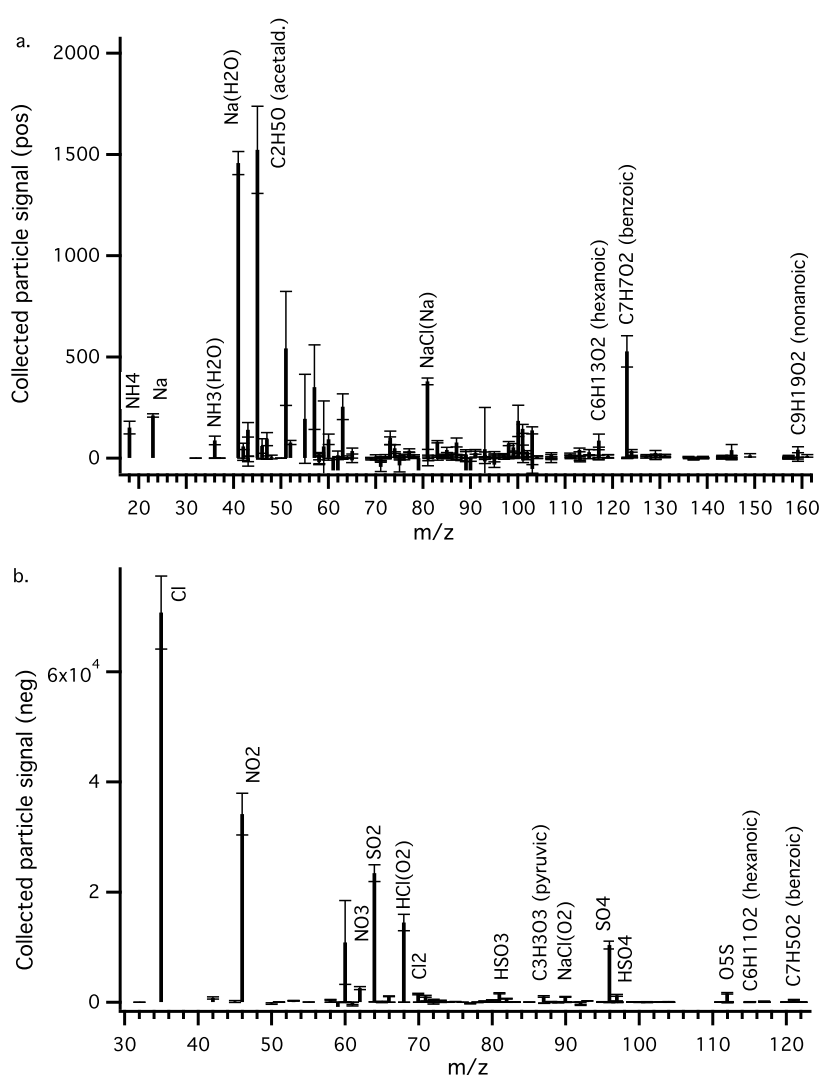

Figure 5. Campaign-averaged high resolution mass spectra of particle composition in (a) positive and (b) negative ion modes, measured by TDCIMS. This is an average of all background-corrected points from 19 to 29 May, and one standard error bars are plotted. Ion identities for species which were at least occasionally detectable are given.

signals, causing the occasional determination of negative particulate nitrate signals. $\mathrm{Br}^{-}$was also occasionally measured at detectable levels, but $\mathrm{I}^{-}$was not detected.

The positive ion spectra were dominated by $\left(\mathrm{H}_{2} \mathrm{O}\right) \mathrm{Na}^{+}$ and sometimes acetaldehyde, $\mathrm{C}_{2} \mathrm{H}_{5} \mathrm{O}^{+}$(Fig. 5a). $\mathrm{Na}^{+}$ tracked the $\left(\mathrm{H}_{2} \mathrm{O}\right) \mathrm{Na}^{+}$signal but was smaller due to ion clustering in the instrument. Acetaldehyde has a high saturation vapor pressure and is therefore most likely a fragmentation product of larger organic compounds. It is very soluble and could therefore be present in aqueous ambient particles, but is nonetheless unexpected to observe because the collected particles are maintained in a dry nitrogen sheath flow before analysis. $\mathrm{A} \mathrm{C}_{7} \mathrm{H}_{7} \mathrm{O}_{2}^{+}$ion was often detected, most likely benzoic acid (based on correlations described below). There were occasional instances when another organic species was found to be above the detection limit, and these are plotted as "organics" in Fig. 1. There were often detectable organic peaks, but very few individual peaks which were consistently detectable. Observed ions include $\mathrm{C}_{9} \mathrm{H}_{19} \mathrm{O}_{2}^{+}$(e.g., nonanoic acid), $\mathrm{C}_{4} \mathrm{H}_{9}^{+}$(butene or methylpropene), $\mathrm{CH}_{3} \mathrm{O}_{2}^{+}$
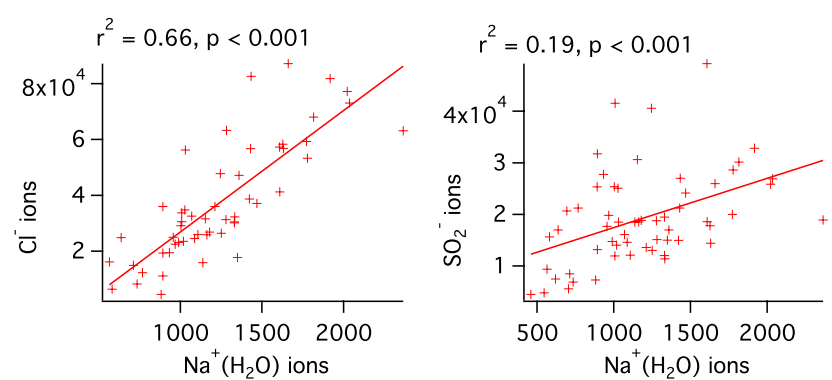

Figure 6. Correlations between the largest sodium peak and the two main negative ions, $\mathrm{Cl}^{-}$and $\mathrm{SO}_{2}^{-}$. Three points prior to midnight on 26 May were excluded, due to very high sulfate levels attributed to a volcanic plume. Both linear slopes are greater than two standard deviations above zero. Most $\mathrm{Cl}^{-}$variability can be attributed to the presence of sea salt, for which sodium is a proxy. The variability in particle sulfate, measured as $\mathrm{SO}_{2}^{-}$, is only explained to a small extent by the presence of sea salt.

(formic acid), $\mathrm{C}_{3} \mathrm{H}_{7} \mathrm{O}^{+}$(acetone or propanal), and $\mathrm{C}_{6} \mathrm{H}_{13} \mathrm{O}_{2}^{+}$ (e.g., hexanoic acid). Many of these may be fragmentation products of larger molecules. There were very few points for which $\mathrm{NH}_{4}^{+}$(ammonium) was above detection, making it difficult to discern patterns. However, ammonium reached its highest fractional abundance during the apparent volcanic plume event on 26 May when a large amount of mass was collected and the highest sulfate levels were observed.

\subsection{TDCIMS ion-ion relationships}

Ratios of ion time series and ion-ion correlations were used to establish relationships and attempt to determine the origin and nature of the observed particles. Only detectable ion points were used. For these tests, data collected from 22 to 29 May were used because the ion source temperature was increased to $80^{\circ} \mathrm{C}$ on the afternoon of 21 May, likely altering relative sensitivities of the different ions. The period from 12:00 on 26 May to 22:00 on 27 May was excluded due to the clear volcanic plume, as evidenced by extremely high sulfate levels and particle numbers.

The observed $\mathrm{Cl}^{-}$closely covaried with $\mathrm{Na}^{+}\left(r^{2}=0.64\right)$ and a $\mathrm{ClNa}_{2}^{+}\left(r^{2}=0.69\right)$ cluster in the positive ion spectrum, indicating the presence of sea salt (Fig. 6). Sulfate was correlated with sodium but less strongly $\left(r^{2}=0.19\right)$, indicating that a large fraction was non-sea-salt sulfate. Sulfate and chloride also correlated with $r^{2}=0.23$. Bromide and chloride were closely correlated for the few detectable bromide points $\left(\mathrm{r}^{2}=0.68\right)$. Acetaldehyde was correlated with sodium $\left(r^{2}=0.32\right)$ and with chloride $\left(r^{2}=0.26\right)$, but not at all with sulfate $\left(r^{2}<0.01\right)$, so it appears to be related to sea spray. The aromatic $\mathrm{C}_{7} \mathrm{H}_{7} \mathrm{O}_{2}^{+}$ion had a fairly weak relationship with $\mathrm{Na}^{+}\left(r^{2}=0.12\right)$ and $\mathrm{Cl}^{-}\left(r^{2}=0.11\right)$, suggesting that it is not a common sea spray component. 
Ion ratios for chloride to sulfate and sulfate to sodium were calculated to assess the relative roles of fresh sea-salt and non-sea-salt sulfate over time (Fig. 1c, d). These ratios are based on the sums of detectable sulfate, sodium, and chloride ions. During the sea-salt period the chloride to sulfate ratio was high, $2.42 \pm 0.22$ ( $1 \mathrm{SD}$ ). It was much lower during the $50 \mathrm{~nm}$ event periods, $1.30 \pm 0.38$. It was intermediate and variable $(1.77 \pm 0.7)$ during the $<50 \mathrm{~nm}$ period, perhaps because the transition to the $50 \mathrm{~nm}$ event period was already beginning to occur. The sea-salt mode is in general prominent in the HTDMA data when the chloride to sulfate ratio is high (Figs. 1a, c). Nonetheless, a significant sulfate ion fraction was still present despite the lack of a strong GF 1.5-1.7 mode in the HTDMA data during the $50 \mathrm{~nm}$ event on 24 May. This is probably due to the abundant $20-40 \mathrm{~nm}$ mode which was sampled by the TDCIMS but not by the HTDMA. There was an event with an extremely high sulfate fraction (about 60 times $\mathrm{Cl}^{-}$) on 26 May, most likely a volcanic plume resulting from the Grímsvötn volcano eruptions of 22-25 May. Air masses during this day came almost directly from the north near Iceland. This was a common air mass back trajectory, also observed during the nanoparticle enhancement events (Fig. 3). The sulfate to sodium ratio showed an inverse pattern to the chloride to sulfate ratio, with higher values during the periods when the sea-salt-hygroscopicity mode was low. The ratio was divided by 10 for the plot to set the lowest values to about 1 (Fig. 1d). These lowest scaled sulfate to sodium values represent an upper limit for the signal ratio of fresh sea spray. Collections with higher values than this certainly contain a non-sea-salt sulfate component, and higher values (1.5-3.5) occur consistently during the long $50 \mathrm{~nm}$ nanoparticle enhancement event beginning on 24 May.

\subsection{Chemistry-particle number relationships}

The fine particle enhancement events were characterized by large enhancement in particle number in the $15-60 \mathrm{~nm}$ range. The sum of the particle number for that range was plotted against the major ions observed to investigate the chemistry of the event particles for the period May 22-28, excluding the period of low mass collection beginning on $28 \mathrm{May}$. The ion showing the strongest correlation $\left(r^{2}=0.39\right)$ was $\mathrm{C}_{7} \mathrm{H}_{7} \mathrm{O}_{2}^{+}$ (Fig. 7). This ion most likely represents benzoic acid, as it correlates reasonably well $\left(r^{2}=0.5\right)$ with $\mathrm{C}_{7} \mathrm{H}_{5} \mathrm{O}_{2}^{-}$(benzoate) in the negative ion spectrum for the very few points when this species was detectable in the negative ion mode. Also, though detectable benzoate points do not correlate well with particle number, benzoate correlates with $r^{2}=0.16$ and $p=0.0045$ if points below detection are included. An alternative molecular identification for the $\mathrm{C}_{7} \mathrm{H}_{7} \mathrm{O}_{2}^{+}$ion is hydroxy benzaldehyde, and we cannot exclude the additional presence of this molecule. $\mathrm{Cl}^{-}, \mathrm{SO}_{2}^{-}, \mathrm{NO}_{2}^{-}$, and $\mathrm{Na}^{+}$all correlate negligibly $\left(r^{2}<0.05, p>0.1\right)$ with the particle number in this size range. Two other organic species show some correlation with the particle enhancements, though at
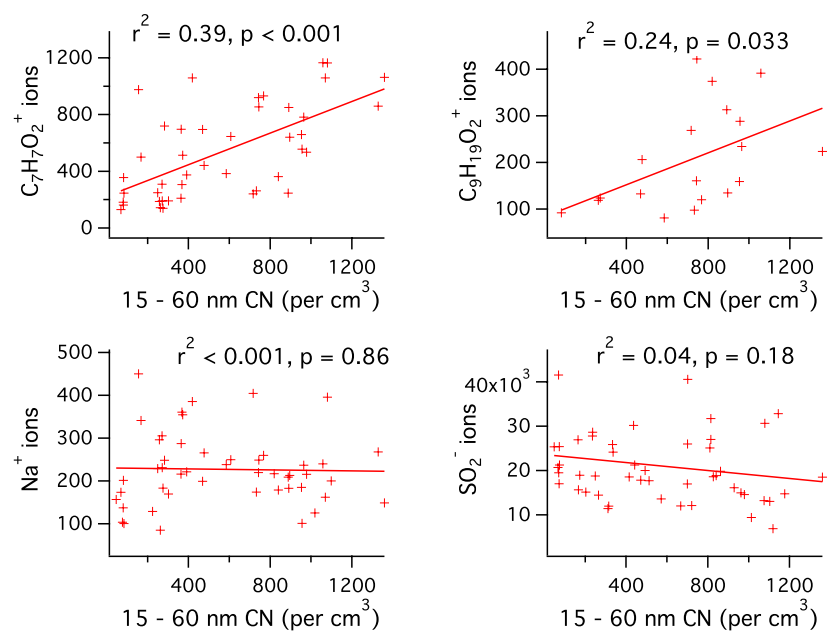

Figure 7. Correlations between individual species measured by TDCIMS and the sum of ambient particle number $(\mathrm{CN})$ in the range of $15-60 \mathrm{~nm}$ during the period 22-28 May. Three points prior to midnight on 26 May were excluded, due to very high sulfate levels attributed to a volcanic plume. The ion most closely associated with the nanoparticle enhancement events is $\mathrm{C}_{7} \mathrm{H}_{7} \mathrm{O}_{2}^{+}$, most likely benzoic acid. Inorganic salts are not correlated with the increases in particle number during this period. Coefficients of determination and $p$ values for the linear fit slope are given.

less statistically significant levels: $\mathrm{C}_{9} \mathrm{H}_{19} \mathrm{O}_{2}^{+}$(e.g., nonanoic acid) at $p=0.033$ and $\mathrm{C}_{6} \mathrm{H}_{13} \mathrm{O}_{2}^{+}$(e.g., hexanoic acid) at $p=$ 0.060 .

\section{Discussion}

There were at least two characteristic particle types in the sub-100 nm size range observed: a very high hygroscopicity mode which had a significant sea-salt component and a lower hygroscopicity mode which had a less certain composition. Both modes were present most of the time. The GF of ammonium sulfate fits within the lower hygroscopicity mode's range (GFs of about 1.5-1.8). However it is also possible that this mode contains mixtures of sulfate, sea salt, and organics.

The nanoparticle enhancement events were characterized by a large increase in particle number in the $15-60 \mathrm{~nm}$ diameter range, in the lower hygroscopicity mode. These events were closely linked to the presence of organic compounds, but not to inorganic components. Number enhancements at slightly smaller sizes during $<50 \mathrm{~nm}$ events indicate growth from very small sizes and are suggestive of new particle formation (Fig. 2). The correlation of the number enhancements with benzoic acid is consistent with laboratory experiments showing enhanced sulfuric acid particle nucleation and growth rates in the presence of benzoic acid (Zhang et al., 2004). The $50 \mathrm{~nm}$ event periods do not show the sub-15 nm enhancement but instead show a shift in the distribution to 
slightly larger sizes. This suggests that the $50 \mathrm{~nm}$ events are a later stage of growth than the $<50 \mathrm{~nm}$ events.

In the $50 \mathrm{~nm}$ event periods, there was an abundance of GF 1.5-1.7 particles, and the GF 2-2.3 mode was almost eliminated. The elimination of the sea-salt mode suggests either that the sea salt which had been present was significantly modified by the events, or that events occurred under conditions of lower sea-salt loading. Given the continued presence of sodium at similar levels throughout the observations, it is more likely that existing sea salt was significantly modified. Therefore, at least some of the lower hygroscopicity mode (GF 1.5-1.7) particles are probably sea-salt-dominated particles which have shifted in GF by the addition of organics and loss of chloride. The constant presence of non-sea-salt sulfate argues that the low hygroscopicity mode contains a significant sulfate fraction as well. Ammonium sulfate has a growth factor of 1.7, and measured pure organic GFs are uniformly lower (Peng et al., 2001; Zardini et al., 2008; Hansson et al., 1998). Growth factors in the range of 1.76-1.85 have been measured for the sodium salts of pyruvic, maleic, malonic, and succinic acids (Peng and Chan, 2001). The same study found growth factors of 2.18 and 1.91 for sodium formate and sodium acetate, respectively. Hygroscopicity measurements of internally mixed $\mathrm{NaCl}$ and benzoic acid particles show that a growth factor of around 1.7 would probably be achieved for about a $2: 1 \mathrm{NaCl}$ : benzoic acid mixture (Shi et al., 2012).

These observations support the hypothesis that sea salt is a regular component of marine aerosol even at very small sizes. Sodium and chloride were observed in essentially all collected particle samples, but neither species was strongly linked to the nanoparticle enhancement events. If sea surface bubble breaking is involved in the generation of the $<50$ and $50 \mathrm{~nm}$ events, its only significant contribution must therefore be organic vapors or organic-rich primary particles, not sea salt. This observation could be consistent with investigations of sea spray generation that show that the sea-salt fraction is small or absent in sub-100 nm particles (Ault et al., 2013). However, if the nanoparticle enhancement events represented direct sea spray emission, significant enhancements in particle number at larger sizes would also be expected based on known sea spray source functions (Fuentes et al., 2010; Clarke et al., 2006), but this was not observed. The presence of organics in seawater has been shown to enhance the production of smaller sea spray particle sizes, potentially resulting in part of the large number enhancements observed at small sizes (Sellegri et al., 2006). This effect alone has been observed to have only a roughly twofold effect on small particle production, however, and does not narrow the distribution of particle sizes generated. It seems likely that preexisting particle phase sea salt was modified by the nanoparticle enhancement events. During these events, the chloride fraction decreases relative to sodium, and for the $50 \mathrm{~nm}$ events, in particular, the sea-salt-hygroscopicity mode is almost gone. During the event on 24 May, there was a relative sulfate in- crease, but in general the nanoparticle enhancements were not correlated with ions from the major inorganic acids (sulfate and nitrate). It seems therefore possible that organic acids provide the acidity required to release $\mathrm{HCl}$ from the particles. Laskin et al. (2012) have shown that weak dicarboxylic acids with high Henry's law constants are able to displace a large fraction of the chloride present in mixed organic/ $\mathrm{NaCl}$ particles under some conditions.

While new particle formation appears to be involved in the fine particle enhancement events, the source of the particle mass remains unclear. The lifetime of very small particles $(\sim 10 \mathrm{~nm})$ is generally less than a few hours (Prospero, 2002), and the nanoparticle enhancement events occurred in marine polar air transported in the boundary layer over a few days, indicating that the particles were formed over the ocean. The duration of the nanoparticle enhancement events implies that this process occurs during both day and night, indicating that photochemistry may not be directly required throughout the particle formation process. Biogenic lipids are present at the sea surface and are thought to contribute to primary marine organic aerosol (Decesari et al., 2011; Kawamura and Sem, 1996; Aluwihare and Repeta, 1999). The observed C9 and C6 alkanoic acids could be derived from the oxidation of volatilized long-chain surface lipids (Kawamura and Sem, 1996; Osterroht, 1993). A likely source for benzoic acid is less clear. Benzoic acid is an oxidation product of aromatic hydrocarbons, and it has been detected in particles following oxidation of aromatics (Forstner et al., 1997). However, aromatics are not expected to be abundant in clean marine air in this region (Hopkins et al., 2002; Lewis et al., 1997). Phenolics are a class of aromatic compounds which have been detected at the sea surface, presumably the result of biological activity (Carlson, 1982; Carlson and Mayer, 1980). Benzoic acid lacks the hydroxyl group of a phenol, but it or its precursors may be generated by pathways similar to those that produce phenols. Petroleum compounds present at the sea surface due to seeps or anthropogenic releases could be another source of aromatic hydrocarbons. These hydrocarbons would need to be volatilized and oxidized in order to generate the benzoic acid which appears to be involved in particle nucleation and growth.

\section{Conclusions}

The chemical composition and hygroscopicity of marine nanoparticles were measured during May 2011 at the coastal site Mace Head. There was essentially always a sea-salt component in the observed aerosol. There was also almost always a separate mode which probably contains sulfate, sea salt, and organics. There were several events during which the number concentrations of 10-60 nm particles increased dramatically. These events appear to involve the nucleation of new particles over the ocean, and these events were connected to increases in organic species in the observed 
particles. The frequency of the nanoparticle enhancement events suggest that they were a major source of fine particles over the study period. If these events are of the same type described by O'Dowd et al. (2010), they may be important for particle number and $\mathrm{CCN}$ availability during much of the spring and summer in the North Atlantic. The composition of marine nanoparticles remains extremely undersampled, and further observations with sensitive instrumentation should be undertaken to understand the formation and aging processes of this aerosol.

\section{The Supplement related to this article is available online at doi:10.5194/acp-14-11557-2014-supplement.}

Acknowledgements. This work was supported by the European Aerosols, Clouds, and Trace gases Research InfraStructure (ACTRIS) Network, the Saastamoinen Foundation, US DOE grant DE-SC0006861, and US NSF grant 0919317. The National Center for Atmospheric Research is supported by the NSF. Air mass history plot provided by Alistair Manning and the Met Office funded by U.K. Department of Energy and Climate Change (GA0201). Thanks to Ru-Jin Huang for comments on the manuscript.

Edited by: J. G. Murphy

\section{References}

Allan, J. D.: Submicron aerosol composition at Trinidad Head, California, during ITCT $2 \mathrm{~K} 2$ : Its relationship with gas phase volatile organic carbon and assessment of instrument performance, J. Geophys. Res., 109, D23S24, doi:10.1029/2003JD004208, 2004.

Allan, J. D., Topping, D. O., Good, N., Irwin, M., Flynn, M., Williams, P. I., Coe, H., Baker, A. R., Martino, M., Niedermeier, N., Wiedensohler, A., Lehmann, S., Müller, K., Herrmann, H., and McFiggans, G.: Composition and properties of atmospheric particles in the eastern Atlantic and impacts on gas phase uptake rates, Atmos. Chem. Phys., 9, 9299-9314, doi:10.5194/acp-9-9299-2009, 2009.

Aluwihare, L. and Repeta, D.: A comparison of the chemical characteristics of oceanic DOM and extracellular DOM produced by marine algae, Mar. Ecol., Progress Series, 186, 105-117, 1999.

Ault, A. P., Guasco, T. L., Ryder, O. S., Baltrusaitis, J., CuadraRodriguez, L. a., Collins, D. B., Ruppel, M. J., Bertram, T. H., Prather, K. a., and Grassian, V. H.: Inside versus outside: ion redistribution in nitric acid reacted sea spray aerosol particles as determined by single particle analysis., J. Am. Chem. Soc., 135, 14528-14531, doi:10.1021/ja407117x, 2013.

Bigg, E. K. and Leck, C.: The composition of fragments of bubbles bursting at the ocean surface, J. Geophys. Res., 113, D11209, doi:10.1029/2007JD009078, 2008.

Breaux, G. A., Benirschke, R. C., and Jarrold, M. F.: Melting, freezing, sublimation, and phase coexistence in sodium chloride nanocrystals., J. Chem. Phys., 121, 6502-6507, doi:10.1063/1.1786921, 2004.
Bzdek, B. R., Zordan, C. a., Luther, G. W., and Johnston, M. V.: Nanoparticle Chemical Composition During New Particle Formation, Aerosol Sci. Technol., 45, 1041-1048, doi:10.1080/02786826.2011.580392, 2011.

Bzdek, B. R., Zordan, C. a., Pennington, M. R., Luther, G. W., and Johnston, M. V.: Quantitative assessment of the sulfuric acid contribution to new particle growth., Environ. Sci. Technol., 46, 4365-4373, doi:10.1021/es204556c, 2012.

Carlson, D.: Surface microlayer phenolic enrichments indicate sea surface slicks, Nature, 296, 426-429, 1982.

Carlson, D. and Mayer, L.: Enrichment of dissolved phenolic material in the surface microlayer of coastal waters, Nature, 286, 482-483, 1980.

Chen, D.-R. and Pui, D.: A high efficiency, high throughput unipolar aerosol charger for nanoparticles, J. Nanopart. Res., 1, 115-126, 1999.

Clarke, A., Kapustin, V., Howell, S., Moore, K., Lienert, B., Masonis, S., Anderson, T., and Covert, D.: Sea-salt size distributions from breaking waves: implications for marine aerosol production and optical extinction measurements during SEAS*, J. Atmos. Ocean. Tech., 20, 1362-1374, doi:10.1175/15200426(2003)020<1362:SSDFBW>2.0.CO;2, 2003.

Clarke, A. D., Owens, S. R., and Zhou, J.: An ultrafine sea-salt flux from breaking waves: Implications for cloud condensation nuclei in the remote marine atmosphere, J. Geophys. Res., 111, 1-14, doi:10.1029/2005JD006565, 2006.

Dall'Osto, M., Monahan, C., Greaney, R., Beddows, D. C. S., Harrison, R. M., Ceburnis, D., and O'Dowd, C. D.: A statistical analysis of North East Atlantic (submicron) aerosol size distributions, Atmos. Chem. Phys., 11, 12567-12578, doi:10.5194/acp11-12567-2011, 2011.

Decesari, S., Finessi, E., Rinaldi, M., Paglione, M., Fuzzi, S., Stephanou, E. G., Tziaras, T., Spyros, a., Ceburnis, D., O’Dowd, C., Dall'Osto, M., Harrison, R. M., Allan, J., Coe, H., and Facchini, M. C.: Primary and secondary marine organic aerosols over the North Atlantic Ocean during the MAP experiment, J. Geophys. Res. Atmos, 116, doi:10.1029/2011JD016204, 2011.

Donahue, N. M., Trump, E. R., Pierce, J. R., and Riipinen, I.: Theoretical constraints on pure vapor-pressure driven condensation of organics to ultrafine particles, Geophys. Res. Lett., 38, L16801, doi:10.1029/2011GL048115, 2011.

Draxler, R. and Hess, G.: Description of the HYSPLIT_4 modeling system. NOAA Tech. Memo ERL ARL-224, Tech. rep., NOAA Air Resources Laboratory, Silver Spring, MD, 1997.

Duplissy, J., Gysel, M., Sjogren, S., Meyer, N., Good, N., Kammermann, L., Michaud, V., Weigel, R., Martins dos Santos, S., Gruening, C., Villani, P., Laj, P., Sellegri, K., Metzger, a., McFiggans, G. B., Wehrle, G., Richter, R., Dommen, J., Ristovski, Z., Baltensperger, U., and Weingartner, E.: Intercomparison study of six HTDMAs: results and recommendations, Atmos. Meas. Tech., 2, 363-378, doi:10.5194/amt-2-363-2009, 2009.

Ehn, M., Vuollekoski, H., Petäjä, T., Kerminen, V.-M., Vana, M., Aalto, P., de Leeuw, G., Ceburnis, D., Dupuy, R., O’Dowd, C. D., and Kulmala, M.: Growth rates during coastal and marine new particle formation in western Ireland, J. Geophys. Res., 115, D18218, doi:10.1029/2010JD014292, 2010.

Ehn, M., Thornton, J. a., Kleist, E., Sipilä, M., Junninen, H., Pullinen, I., Springer, M., Rubach, F., Tillmann, R., Lee, B., LopezHilfiker, F., Andres, S., Acir, I.-H., Rissanen, M., Jokinen, T., 
Schobesberger, S., Kangasluoma, J., Kontkanen, J., Nieminen, T., Kurtén, T., Nielsen, L. B., Jø rgensen, S., Kjaergaard, H. G., Canagaratna, M., Maso, M. D., Berndt, T., Petäjä, T., Wahner, A., Kerminen, V.-M., Kulmala, M., Worsnop, D. R., Wildt, J., and Mentel, T. F.: A large source of low-volatility secondary organic aerosol, Nature, 506, 476-479, doi:10.1038/nature13032, 2014.

Eisele, F. L. and McMurry, P. H.: Recent progress in understanding particle nucleation and growth, Philos. T. R. Soc. B, 352, 191201, doi:10.1098/rstb.1997.0014, 1997.

Fitzgerald, J. W.: Marine Aerosols: A Review, Atmos. Environ., 25, 533-545, 1991.

Forstner, H. J., Flagan, R. C., and Seinfeld, J. H.: Secondary organic aerosol from the photooxidation of aromatic hydrocarbons: Molecular composition, Environ. Sci., 31, 1345-1358, doi:10.1021/es9605376, 1997.

Fuentes, E., Coe, H., Green, D., de Leeuw, G., and McFiggans, G.: Laboratory-generated primary marine aerosol via bubblebursting and atomization, Atmos. Meas. Tech., 3, 141-162, doi:10.5194/amt-3-141-2010, 2010.

George, C., Bernard, F., Ciuraru, R., Rossignol, S., and Fine, L.: Air-sea exchanges driven by light, SOLAS Newsletter 16, 1617, 2014.

Good, N., Coe, H., and McFiggans, G.: Instrumentational operation and analytical methodology for the reconciliation of aerosol water uptake under sub- and supersaturated conditions, Atmos. Meas. Tech., 3, 1241-1254, doi:10.5194/amt-3-1241-2010, 2010.

Gysel, M., McFiggans, G., and Coe, H.: Inversion of tandem differential mobility analyser (TDMA) measurements, J. Aerosol Sci., 40, 134-151, doi:10.1016/j.jaerosci.2008.07.013, 2009.

Hansson, H., Rood, M., Koloutsou-Vakakis, S., Hämeri, K., Orsini, D., and Wiedensohler, $\mathrm{A}$.: $\mathrm{NaCl}$ aerosol particle hygroscopicity dependence on mixing with organic compounds, J. Atmos. Chem., 31, 321-346, 1998.

Heintzenberg, J., Covert, D. C., and Van Dingenen, R.: Size distribution and chemical composition of marine aerosols: a compilation and review, Tellus B, 52B, 1104-1122, doi:10.1034/j.16000889.2000.00136.x, 2000.

Hersey, S. P., Sorooshian, A., Murphy, S. M., Flagan, R. C., and Seinfeld, J. H.: Aerosol hygroscopicity in the marine atmosphere: a closure study using high-time-resolution, multiple-RH DASHSP and size-resolved C-ToF-AMS data, Atmos. Chem. Phys., 9, 2543-2554, doi:10.5194/acp-9-2543-2009, 2009.

Hopkins, J., Jones, I., a.C Lewis, McQuaid, J., and Seakins, P.: Non-methane hydrocarbons in the Arctic boundary layer, Atmos. Environ., 36, 3217-3229, doi:10.1016/S1352-2310(02)00324-2, 2002

Hoppel, W., Frick, G., and Larson, R.: Effect of nonprecipitating clouds on the aerosol size distrbution in the marine boundary layer, Geophys. Res., 13, 125-128, doi:10.1029/GL013i002p00125, 1986.

Hoppel, W. a., Frick, G. M., and Fitzgerald, J. W.: Deducing droplet concentration and supersaturation in marine boundary layer clouds from surface aerosol measurements, J. Geophys. Res., 101, 26553, doi:10.1029/96JD02243, 1996.

Kawamura, K. and Sem, R.: Water soluble dicarboxylic acids and related compounds in Antarctic aerosols, 101, 18721-18728, 1996.
Khvorostyanov, V. I. and Curry, J. a.: Refinements to the Köhler's theory of aerosol equilibrium radii, size spectra, and droplet activation: Effects of humidity and insoluble fraction, J. Geophys. Res., 112, D05206, doi:10.1029/2006JD007672, 2007.

Kuang, C., McMurry, P. H., McCormick, A. V., and Eisele, F. L.: Dependence of nucleation rates on sulfuric acid vapor concentration in diverse atmospheric locations, J. Geophys. Res., 113, 1-9, doi:10.1029/2007JD009253, 2008.

Kuang, C., Chen, M., Zhao, J., Smith, J., McMurry, P. H., and Wang, J.: Size and time-resolved growth rate measurements of 1 to $5 \mathrm{~nm}$ freshly formed atmospheric nuclei, Atmos. Chem. Phys., 12, 3573-3589, doi:10.5194/acp-12-3573-2012, 2012.

Kulmala, M., Vehkamäki, H., Petäjä, T., Dal Maso, M., Lauri, a., Kerminen, V.-M., Birmili, W., and McMurry, P.: Formation and growth rates of ultrafine atmospheric particles: a review of observations, J. Aerosol Sci., 35, 143-176, doi:10.1016/j.jaerosci.2003.10.003, 2004.

Laskin, A., Moffet, R. C., Gilles, M. K., Fast, J. D., Zaveri, R. a., Wang, B., Nigge, P., and Shutthanandan, J.: Tropospheric chemistry of internally mixed sea salt and organic particles: Surprising reactivity of $\mathrm{NaCl}$ with weak organic acids, J. Geophys. Res., 117, D15302, doi:10.1029/2012JD017743, 2012.

Lewis, A. C., Bartle, K. D., Heard, D. E., Mcquaid, J. B., Pilling, M. J., and Seakins, P. W.: In situ, gas chromatographic measurements of non-methane hydrocarbons and dimethyl sulfide at a remote coastal location (Mace Head, Eire) July-August 1996, 93, 2921-2927, 1997.

Mäkelä, J. M.: Biogenic iodine emissions and identification of endproducts in coastal ultrafine particles during nucleation bursts, $\mathrm{J}$ Geophys. Res., 107, 8110, doi:10.1029/2001JD000580, 2002.

McFiggans, G., Bale, C. S. E., Ball, S. M., Beames, J. M., Bloss, W. J., Carpenter, L. J., Dorsey, J., Dunk, R., Flynn, M. J., Furneaux, K. L., Gallagher, M. W., Heard, D. E., Hollingsworth, A. M., Hornsby, K., Ingham, T., Jones, C. E., Jones, R. L., Kramer, L. J., Langridge, J. M., Leblanc, C., LeCrane, J.-P., Lee, J. D., Leigh, R. J., Longley, I., Mahajan, A. S., Monks, P. S., Oetjen, H., Orr-Ewing, A. J., Plane, J. M. C., Potin, P., Shillings, A. J. L., Thomas, F., von Glasow, R., Wada, R., Whalley, L. K., and Whitehead, J. D.: Iodine-mediated coastal particle formation: an overview of the Reactive Halogens in the Marine Boundary Layer (RHaMBLe) Roscoff coastal study, Atmos. Chem. Phys., 10, 2975-2999, doi:10.5194/acp-10-2975-2010, 2010.

Mcinnes, L., Covert, D., and Baker, B.: The number of sea-salt, sulfate, and carbonaceous particles in the marine atmopshere: EM Measurements consistent with the ambient size distribution, Tellus B, 49B, 303-313, doi:10.1034/j.1600-0889.49.issue3.6.x, 1997.

McMurry, P., Ghimire, A., Ahn, H.-K., Sakurai, H., Moore, K., Stolzenburg, M., and Smith, J.: Sampling nanoparticles for chemical analysis by low resolution electrical mobility classification, Environ. Sci. Technol., 43, 4653-4658, doi:10.1021/es8029335, 2009.

McMurry, P. H.: New particle formation in the presence of an aerosol: rates, time scales, and sub- $0.01 \mu \mathrm{m}$ size distributions, J. Colloid Interf. Sci., 95, 72-80, 1983.

O’Dowd, C., Monahan, C., and Dall'Osto, M.: On the occurrence of open ocean particle production and growth events, Geophys. Res. Lett., 37, L19805, doi:10.1029/2010GL044679, 2010. 
O'Dowd, C. D. and de Leeuw, G.: Marine aerosol production: a review of the current knowledge, Philosophical transactions. Series A, Mathematical, physical, and engineering sciences, 365, 1753-74, doi:10.1098/rsta.2007.2043, 2007.

O'Dowd, C. D. and Hoffmann, T.: Coastal New Particle Formation: A Review of the Current State-Of-The-Art, Environmental Chemistry, 2, 245, doi:10.1071/EN05077, 2005.

Osterroht, C.: Extraction of dissolved fatty acids from sea water, Fresenius' Journal of Analytical Chemistry, 345, 773-779, 1993.

Peng, C. and Chan, C. K.: The water cycles of water-soluble organic salts of atmospheric importance, Atmospheric Environment, 35, 1183-1192, doi:10.1016/S1352-2310(00)00426-X, 2001.

Peng, C., Chan, M. N., and Chan, C. K.: The hygroscopic properties of dicarboxylic and multifunctional acids: measurements and UNIFAC predictions., Environmental science \& technology, 35, 4495-501, 2001.

Pierce, J. R. and Adams, P. J.: Global evaluation of $\mathrm{CCN}$ formation by direct emission of sea salt and growth of ultrafine sea salt, Journal of Geophysical Research, 111, D06203, doi:10.1029/2005JD006186, 2006.

Prospero, J.: The Chemical and Physical Properties of Marine Aerosols: An Introduction, in: Chemistry of Marine Water and Sediments, edited by GIanguzza, A., Pellizzetti, E., and Ammarano, S., chap. 2, pp. 3-82, Springer-Verlag, Heidelberg, 2002.

Russell, L. M. and Singh, E. G.: Submicron Salt Particle Production in Bubble Bursting, Aerosol Science and Technology, 40, 664671, doi:10.1080/02786820600793951, 2006.

Seinfeld, J. H. and Pandis, S. N.: Atmospheric Chemistry and Physics: From Air Pollution to Climate Change, WileyInterscience, Hoboken, NJ, 1997.

Sellegri, K., O'Dowd, C. D., Yoon, Y. J., Jennings, S. G., and de Leeuw, G.: Surfactants and submicron sea spray generation, J. Geophys. Res., 111, D22215, doi:10.1029/2005JD006658, 2006.

Shi, Y., Ge, M., and Wang, W.: Hygroscopicity of internally mixed aerosol particles containing benzoic acid and inorganic salts, Atmos. Environ., 60, 9-17, doi:10.1016/j.atmosenv.2012.06.034,2012.

Sirdeshmukh, D., Sirdeshmukh, L., and Subhadra, K.: Alkali Halides: A Handbook of Physical Properties, Springer, Heidelberg, 2001.

Sjogren, S., Gysel, M., Weingartner, E., Baltensperger, U., Cubison, M., Coe, H., a.a. Zardini, Marcolli, C., Krieger, U., and Peter, T.: Hygroscopic growth and water uptake kinetics of two-phase aerosol particles consisting of ammonium sulfate, adipic and humic acid mixtures, J. Aerosol Sci., 38, 157-171, doi:10.1016/j.jaerosci.2006.11.005, 2007.

Smith, J. N. and Rathbone, G. J.: Carboxylic acid characterization in nanoparticles by thermal desorption chemical ionization mass spectrometry, Int. J. Mass Spectrom., 274, 8-13, doi:10.1016/j.ijms.2008.04.008, 2008.

Smith, J. N., Moore, K. F., McMurry, P. H., and Eisele, F. L.: Atmospheric Measurements of Sub-20 nm Diameter Particle Chemical Composition by Thermal Desorption Chemical Ionization Mass Spectrometry, Aerosol Sci. Technol., 38, 100-110, doi:10.1080/02786820490249036, 2004.

Solomon, S., Qin, D., Manning, M., Chen, Z., Marquis, M., Averyt, K., Tignor, M., and Miller, H.: IPCC 2007: Climate Change 2007: The Physical Science Basis. Contribution of Working Group I to the Fourth Assessment Report of the Intergovernmen- tal Panel on Climate Change, Tech. Rep., Cambridge University Press, Cambridge, 2007.

Spracklen, D. V., Carslaw, K. S., Kulmala, M., Kerminen, V.-M., Mann, G. W., and Sihto, S.-L.: The contribution of boundary layer nucleation events to total particle concentrations on regional and global scales, Atmos. Chem. Phys., 6, 5631-5648, doi:10.5194/acp-6-5631- 2006, 2006.

Spracklen, D. V., Carslaw, K. S., Merikanto, J., Mann, G. W., Reddington, C. L., Pickering, S., Ogren, J. a., Andrews, E., Baltensperger, U., Weingartner, E., Boy, M., Kulmala, M., Laakso, L., Lihavainen, H., Kivekäs, N., Komppula, M., Mihalopoulos, N., Kouvarakis, G., Jennings, S. G., O’Dowd, C., Birmili, W., Wiedensohler, a., Weller, R., Gras, J., Laj, P., Sellegri, K., Bonn, B., Krejci, R., Laaksonen, a., Hamed, a., Minikin, a., Harrison, R. M., Talbot, R., and Sun, J.: Explaining global surface aerosol number concentrations in terms of primary emissions and particle formation, Atmos. Chem. Phys., 10, 4775-4793, doi:10.5194/acp-10-4775-2010, 2010.

Topping, D. O., McFiggans, G. B., and Coe, H.: A curved multicomponent aerosol hygroscopicity model framework: Part 1 - Inorganic compounds, Atmos. Chem. Phys., 5, 1205-1222, doi:10.5194/acp-5-1205-2005, 2005.

Voisin, D., Smith, J., Sakurai, H., McMurry, P., and Eisele, F.: Thermal Desorption Chemical Ionization Mass Spectrometer for U1trafine Particle Chemical Composition, Aerosol Sci. Technol., 37, 471-475, doi:10.1080/02786820390125232, 2003.

Wang, M. and Penner, J. E.: Aerosol indirect forcing in a global model with particle nucleation, Atmos. Chem. Phys., 9, 239-260, doi:10.5194/acp-9-239-2009, 2009.

Whitehead, J., McFiggans, G., Gallagher, M., and Flynn, M.: Simultaneous coastal measurements of ozone deposition fluxes and iodine-mediated particle emission fluxes with subsequent CCN formation, Atmos. Chem. Phys., 10, 255-266, doi:8110.1029/2000JD000206, 2010.

Whitehead, J. D., McFiggans, G. B., Gallagher, M. W., and Flynn, M. J.: Direct linkage between tidally driven coastal ozone deposition fluxes, particle emission fluxes, and subsequent CCN formation, Geophys. Res. Lett., 36, L04806, doi:10.1029/2008GL035969, 2009.

Wu, Z. J., Nowak, a., Poulain, L., Herrmann, H., and Wiedensohler, a.: Hygroscopic behavior of atmospherically relevant watersoluble carboxylic salts and their influence on the water uptake of ammonium sulfate, Atmospheric Chemistry and Physics, 11, 12617-12626, doi:10.5194/acp-11-12617-2011, 2011.

Yu, F. and Luo, G.: Simulation of particle size distribution with a global aerosol model: contribution of nucleation to aerosol and CCN number concentrations, Atmos. Chem. Phys., 9, 76917710, doi:10.5194/acp-9-7691-2009, 2009.

Zardini, a. a., Sjogren, S., Marcolli, C., Krieger, U. K., Gysel, M., Weingartner, E., Baltensperger, U., and Peter, T.: A combined particle trap/HTDMA hygroscopicity study of mixed inorganic/organic aerosol particles, Atmos. Chem. Phys., 8, 55895601, doi:10.5194/acp-8-5589-2008, 2008.

Zhang, R., Suh, I., Zhao, J., Zhang, D., Fortner, E. C., Tie, X., Molina, L. T., and Molina, M. J.: Atmospheric new particle formation enhanced by organic acids., Science (New York, N.Y.), 304, 1487-1490, doi:10.1126/science.1095139, 2004. 
Zhang, R., Khalizov, A., Wang, L., Hu, M., and Xu, W.: Nucleation and growth of nanoparticles in the atmosphere, Chem. Rev., 112, 1957-2011, doi:10.1021/cr2001756, 2012.
Zhang, S.-H., Akutsu, Y., Russell, L. M., Flagan, R. C., and Seinfeld, J. H.: Radial Differential Mobility Analyzer, Aerosol Sci. Technol., 12, 357-372, 1995. 